\title{
CHARACTERISATION AND EVALUATION OF COLUMNAR BASALT GEOHERIATGE IN THAILAND: IMPLICATION FOR GEOTOURISM MANAGEMENT IN POST-QUARRYING AREA
}

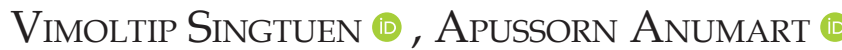 \\ Department of Geotechnology, Khon Kaen University, Khon Kaen, Thailand \\ Manuscript received: October 3, 2021 \\ Revised version: January 4, 2022
}

\begin{abstract}
Singtuen V., ANUmART A., 2022. Characterisation and evaluation of columnar basalt geoheriatge in Thailand: Implication for geotourism management in post-quarring area. Quaestiones Geographicae 41(1), Bogucki Wydawnictwo Naukowe, Poznań, pp. 37-50. 11 figs, 2 tables.

ABSTRACT: Late Cenozoic basaltic rocks in Nang Rong Columnar Jointed Basalts in southern Khorat Plateau are among the greatest columnar basalts in Thailand as famous geoheritage sites. This work aims to characterize and evaluate the post-quarrying area by field investigation, petrography, geochemistry, and geological engineering. A petrographical study determines these basalts as olivine basalts, presenting porphyritic texture with olivine microphenocryst. Geochemical characteristics indicate these basalts were alkaline basalt generated from alkaline sodic magma series within the continental plates. In addition, columnar jointed basalt presents compressive strength and point load strength index higher than platy basalt with a higher percentage of alteration. Local authorities enhance people in the area to develop and promote their georesources through touristic activities. This geoheritage demonstrates high geology and tourism management values; thus, it could be the prototype of the post-quarrying geosite of Thailand.
\end{abstract}

KEY WORDS: geoheritage, geology, volcanic rock, olivine basalt, geochemistry, quarry

Corresponding author: Vimoltip Singtuen, vimosi@kku.ac.th

\section{Introduction}

In Thailand, the most significant metallic minerals are tin, tungsten, niobium, tantalum, lead, zinc, gold, iron and stibnite (DMR 2001). Nonmetallic minerals such as feldspar, clay minerals, fluorite, barite, potash and rocksalt are also significant. In addition, rocks and dimension stones are becoming more significant as industrial and building resources (Fig. 1a). Thailand has 213 mines on records listed by the United States Geological Survey (USGS 2021). Tin, antimony and tungsten are the most regularly cited main commodities in Thailand mines. A total of 43 mines in Thailand were discovered to contain ore mineralisation in an outcrop, shallow pit or isolated drill hole at the time these mines were inspected, which is known as an occurrence mine. Thailand has a total of 30 potential mines. At the time the data was put into USGS records, 133 mines were in operation (Fig. 1b). The significant developing post-mining areas consist chiefly of ore mining (tin, zinc, copper, lead and gold) in western, southern, and north-central parts, coal mining (Lampang and Loei), clay mining (Lampang), gemstone mining (Kanchanaburi, Trat, and Chantaburi) and rock quarry all over this region (Fig. 1b). However, these sites were not considered as a good place for tourism or education, following the policy of the Department 


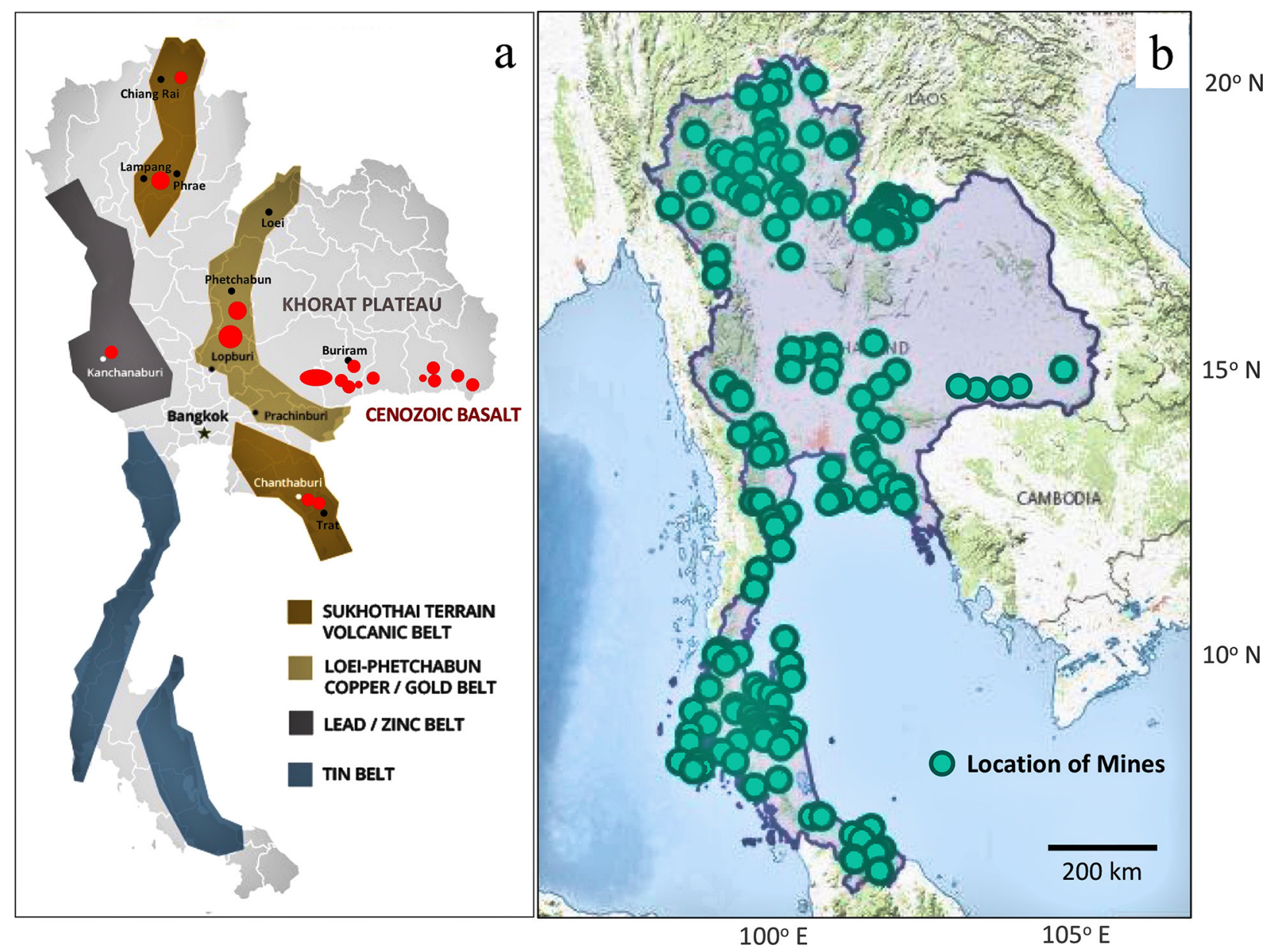

Fig. 1. a - Thai metallogenic belt and b - location of mining in Thailand (modified from The diggings ${ }^{\odot}$ program and data from USGS (2021)).

of Primary Industries and Mines and Department of Mineral Resources. This point is one of the most critical problems of environmental management in Thailand. There are many works to study about the issue of geotourism in the outstanding geosites of Thailand, excluding the post-mining area (Singtuen, Won-In 2017, 2018a, b, Nazaruddin 2019, 2020, Singtuen et al. 2019, Singtuen, Phajuy 2020). The main goal of this research is to define the development guidelines of the post-mining areas as good sites of attractions and geoeducation sites through geotourism, which will be framed in the network of geoethics (Bohle, Capua 2019, Bohle et al. 2019, Di Capua, Peppoloni 2019). There are two outstanding sites of columnar jointed basalts in Thailand, i.e. Phrae and Phetchabun provinces (Cenozoic basalts of Northern Thailand). The Nang Rong Columnar Jointed Basalts, Buriram province, is an in-trend famous destination for tourists (newly discovered site) and its distinctive feature is the largest columnar in Thailand as presented in post-mining areas or old rock quarry for construction (Fig. 2). These basalts could also be developed as a geoheritage for educating local people and tourists to understand the geologic history and earth's process in this area.

The Late Cenozoic basalts are distributed throughout Thailand, including Chiang Rai, Lampang, Kanchanaburi, Nakhon Ratchasima, Phetchabun, Lopburi, Chanthaburi, Rayong, Trat, Sisaket, Surin, and Buriram (Fig. 1a). Most of the basalt in Thailand erupted during the Cenozoic Era (66.4 ma), which was a continuation of the Indian and Eurasian Plateaus (Barr, Macdonald 1981, Yan et al. 2018), divided into three main groups: Basanitoid basalt, Hawaiiitic basalt, and Tholeiitic basalt (Barr, MacDonald 1981). Buriram is one of the provinces in the southern part of the Khorat Plateau with many volcanic features. Barr and MacDonald (1981) suggest that the basalts in Buriram Province erupted as lava flow in the 


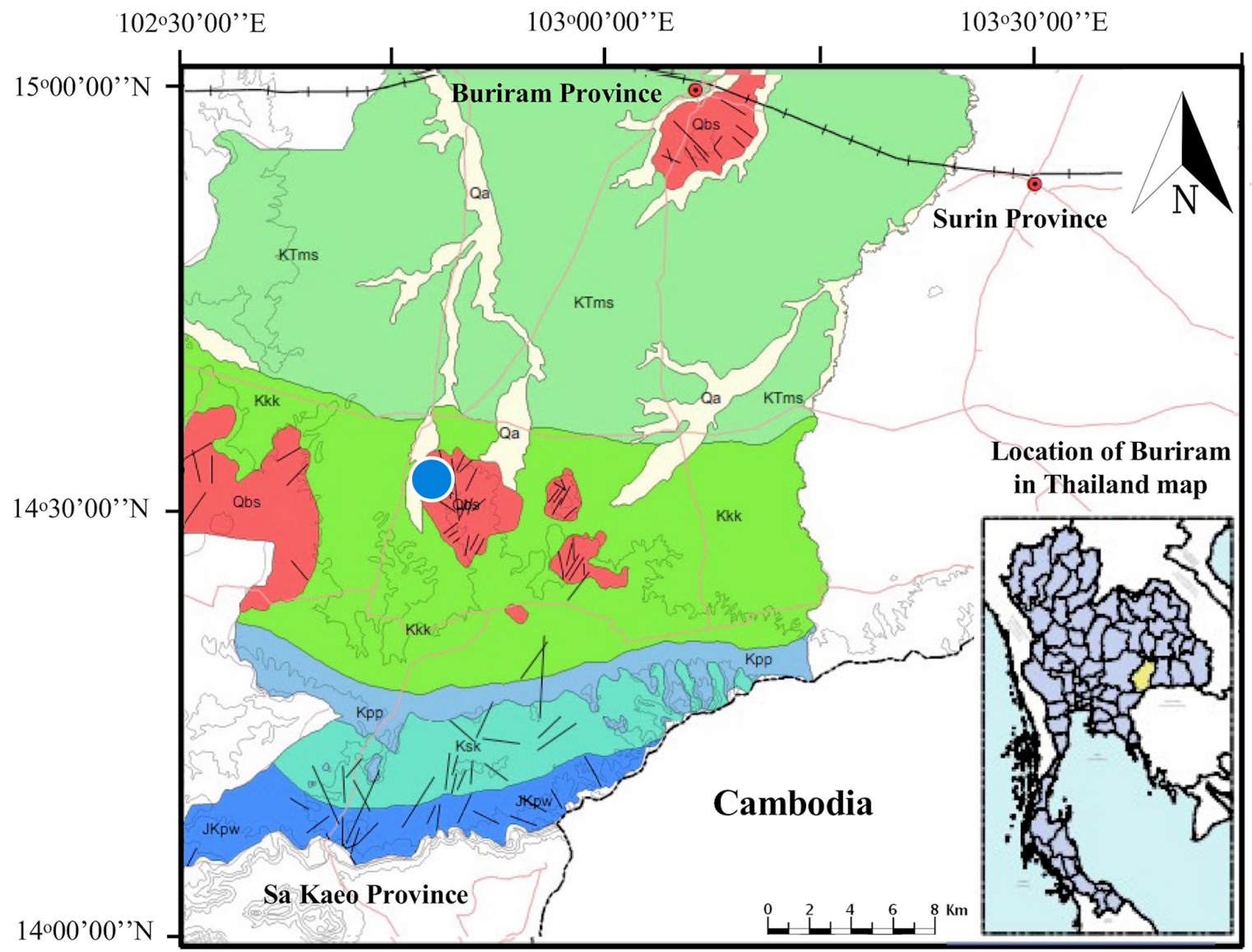

Explanation

sedimentary rocks

Qa alluvial deposits, gravel, sand, silt, and clay accumulate in ditches, embankments, rivers, and flood basins.

Qc colluvial deposits and weathered deposits, gravel, sand, silt, laterite, and rubble.

Qt terrace deposits, gravel, sand, silt, clay, and laterite

KTms reddish-brown, red siltstone, claystone, and sandstone. mostly were found rock salt, potash, gypsum, and anhydrite.

Kkk siltstone reddish-brown, red calcareous sandstone, claystone, and parallel calcrete conglomerate

Kpp gray, grayish-green, brown sandston mostly found gravel and thick bedding siltstone and pebble sandstone consists of quartz chert jasper and igneous rocks

Ksk reddish-brown, reddish-purple, and red sitstone and sandstone has mostly calcrete and parallel inner silcrete

$\mathrm{JKpw}$ white, pink, and gray arenite showed thick cross bedding interbed with pebble sandstone and thin red siltstone claystone

Jpk purple and reddish-purple siltstone with calcareous and mica greenish-gray and yellowishbrown sandstone and conglomerate with parallel calcrete

igneous rocks

Qbs alkaline olivine basalt, hawaiian, muerrite, nephelineite, basalite, and nepheline hawaiian.

Symbols

study area
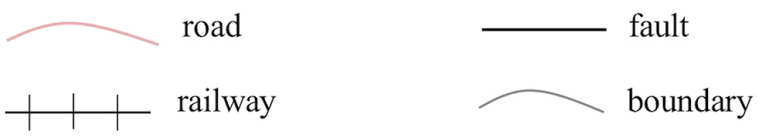

Fig. 2. Geologic map of Buriram Province, presenting Nang Rong Columnar Jointed Volcanics in blue circle (DMR 2001, modified). 
Pleistocene age $(0.92 \pm 0.3 \mathrm{Ma})$. Although there are many studies about basalt in Buriram, there has not been much research describing the relationship between geology and geo-engineering. This work also determines the origin of basalt, both the columnar joint and the platy joint, linking with their engineering properties, which is interesting. According to the lava flow, the initial cooling from the surface, and its sudden change in temperature to form hard rock, will result in the lava to contract and create a tensile force more significant than the surrounding expansion, and hence isotherms are assumed to be perpendicular to the direction of the columns (Hetenyi et al. 2012, Tietz et al. 2018, Hamada, Toramaru 2020, Li, Liu 2020). The lava that lies beneath the earth cools slowly; the crack extends down the magma until its pull is equal to its expansion, which causes a columnar joint inside and a platy joint on the surface (Mallet 1875, Middlemost 1975).

\section{Geology of the study area}

The Nang Rong Columnar Jointed Basalts is located at Ban Khok Makha Ron, Sadao Subdistrict, Nang Rong District, the southern part of Buriram province. Field observations and literature reviews (DMR 2007) suggest that sedimentary and igneous rocks are distributed in the studied area. Khok Kruat Formation (Fig. 2) is composed of sedimentary rocks consisting of reddish-brown and purplish-red sandstone, siltstone, mudstone, and rounded pebbles. Cal caliche is found at the top of the mudstone. This formation is distributed in the east-west strike with a subhorizontal dip to the north, conforming with the Phu Phan formation on the top. Igneous rocks are found as only basalt rocks with dense, vesicular texture, and some of them are amygdaloidal texture, flowed over Khok Kruat Formation. Geological structures in the area are classified as fault, fold and unconformity (Fig. 2).

\section{Methodology}

The methodology consists of geological field investigation, characterisation, classification, assessment and discussion. This research was carried out from October 2020 to September 2021.
The prime aim is to make a geological field investigation at the site, which is demonstrated as an old rock quarry for producing basalt aggregate in the past. After that, authors characterised and classified location, joint patterns, size, rock type, mineral compositions, and occurrence by petrography, geochemistry and engineering geology.

Twelve samples were collected from the investigated area for petrographical study and photomicrograph analysis by ZEN core Imaging Software, linking ZEISS imaging and microscope solutions at the Department of Geotechnology, Khon Kaen University.

The geochemistry of four selected samples was studied by Phillip-MagixPro PW 2400 Wavelength Dispersive X-Ray Fluorescence spectrometer at the Department of Geological Sciences, Chiang Mai University, for analysing major elements, while Olympus Vanta handheld XRF analysers analysed their trace elements at the Department of Geotechnology, Khon Kaen University. Loss on ignition (LOI) was measured by heating a platinum crucible containing a $1.0 \mathrm{~g}$ sample in a furnace at $1000^{\circ} \mathrm{C}$ for $12 \mathrm{~h}$ at the Department of Architecture, Khon Kaen University.

The geological engineering consists of the compressive strength (CS) converted from impact strength by Schmidt hammer, testings in the field with ASTM D 5873XX (ASTM 2014) in 20 columnar basalts ( $Y, X$ and $T$ shape crack) and 20 platy basalts. The point load strength analyses of twenty columnar basalt samples and twenty platy basalt samples were carried out following ISRM test standards 1985XX (ISRM 1985) at the Department of Geotechnology, Khon Kaen University. The formula used in the point load test is as follows in Eqs 1-3 where Is is the point load index (MPa), and $P$ is load $(\mathrm{N}) . D$ is defined as equivalent core diameter $(\mathrm{mm})$, while $F$ means the geometric correction factor. In addition, $I s_{50}$ represents the point load index normalised to a cylindrical specimen of $50 \mathrm{~mm}$ in diameter (MPa).

$$
I s=\frac{P}{D^{2}}
$$

$$
\begin{aligned}
& F=\left(\frac{D}{50}\right)^{0.45} \\
& I s_{50}=F \times I s
\end{aligned}
$$


Assessments and strategic planning techniques were conducted based on the evaluation of the experiences of the authors, local people, and tourists to discuss the potential of geotourism in the area. The assessment method focuses on tourism strategy, management, activities of both local people and visitors, as well as promotion. Moreover, strengths-weaknesses-opportunities-threats (SWOT) analysis focuses on strengths, weaknesses, opportunities and threats for geoheritage and geotourism development. These characteristics of basalt are important for describing the origin of basaltic flow, columnar occurrence and reason for quarrying, which serve to develop a better understanding of the geotourism aspect of the region.
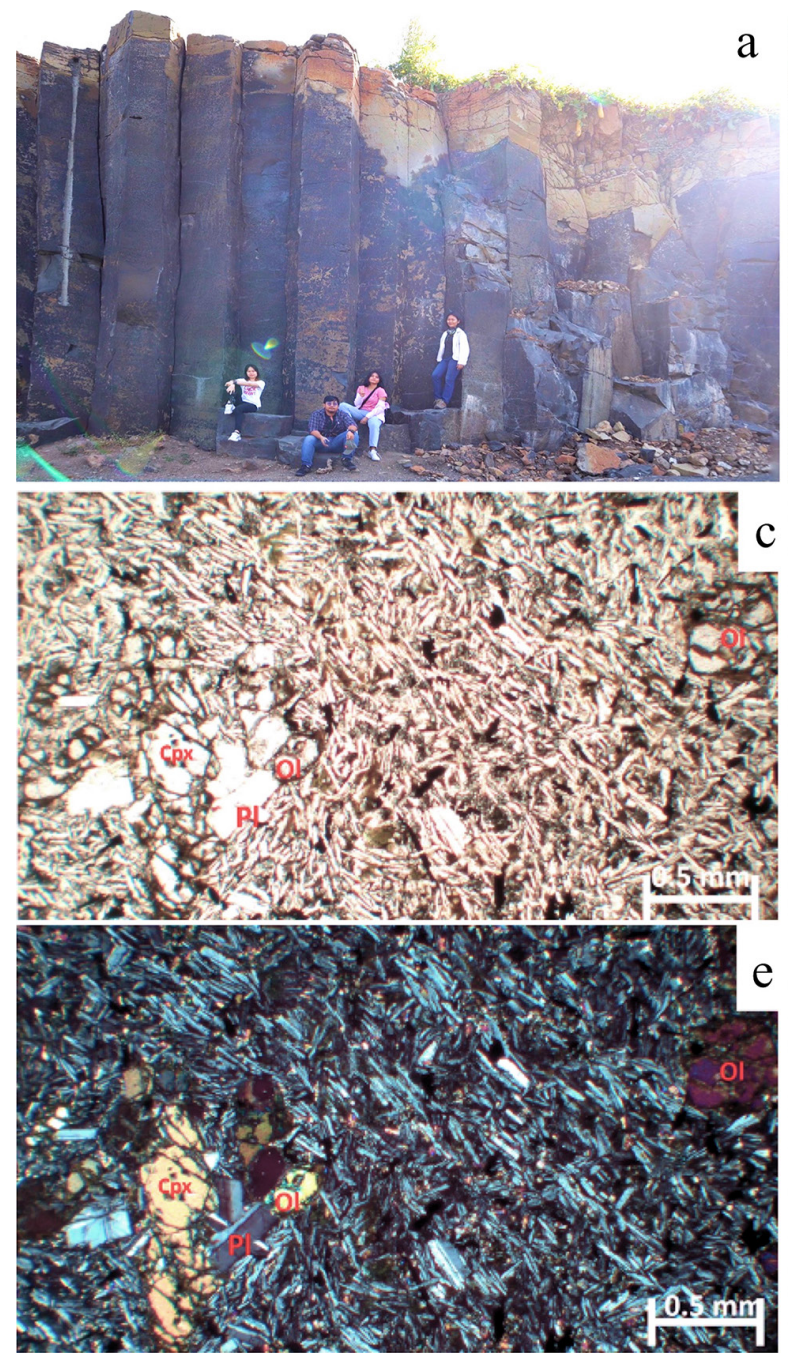

\section{Characterisation}

The area presents many geodiversities, which include rock, landform and rock-construction resources. However, the scope of the area could have potential in petrological, mineralogical and geomorphological sites. This geoheritage is characterised and classified by petrography, geochemistry and engineering geology.

\section{Petrography}

The volcanic outcrop at Nang Rong Columnar Jointed Basalts is found in the old quarry (Fig. $3 \mathrm{a}, \mathrm{b})$. The studied rocks can be determined as olivine basalt based on mineral compositions

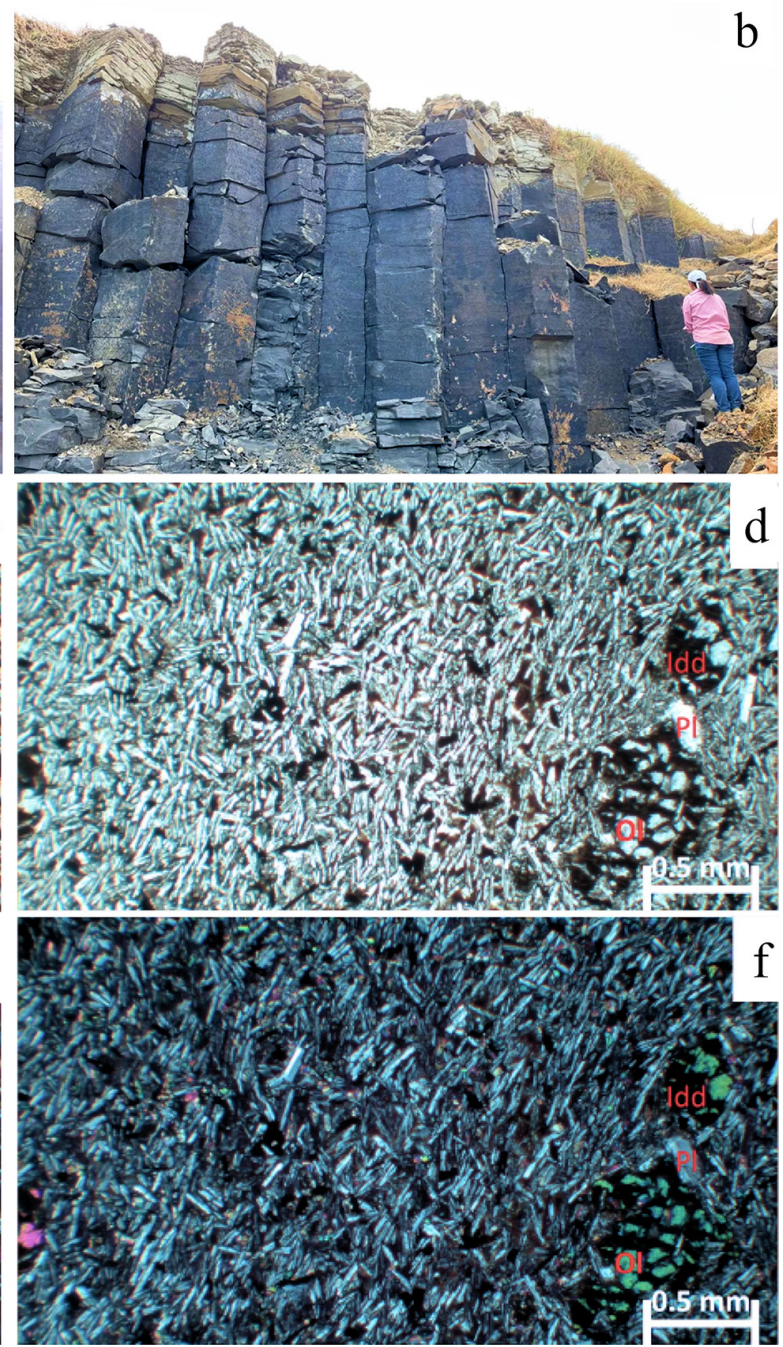

Fig. 3. Outcrop of Nang Rong Columnar Jointed Volcanics a - columnar joint, b - platy joint. The photomicrographs of olivine basalt showing porphyritic texture c - columnar basalt in Nang Rong Columnar Jointed Volcanics in plane-polarized light, e - crossed polarized light, $\mathrm{d}$ - platy basalt in Nang Rong Columnar Jointed Volcanics in plane-polarized light, $\mathrm{f}$ - crossed polarized light. Ol, olivine; Cpx, clinopyroxene; Pl, plagioclase; Idd, iddingsite. 
and present porphyritic texture with olivine microphenocrysts. The groundmass of these olivine basalts consists mainly of plagioclase, with a small amount of olivine, clinopyroxene and opaque minerals. Olivine microphenocrysts are slightly altered to iddingsite. Groundmass plagioclase shows trachytic texture, indicating that this basalt erupted as a lava flow (Fig. 3).

Furthermore, basalt in the Nang Rong Columnar Jointed Basalts area found the quantity of iddingsite, an amorphous alteration of mafic microphenocrysts, crystallising in platy basalt (15.70 modal\%) more than columnar basalt (10.06 $\operatorname{modal} \%)$.

\section{Geochemistry}

The geochemical analysis identified four selected samples in the study area are shown in
Table 1. Major oxides $\left(\mathrm{Na}_{2} \mathrm{O}+\mathrm{K}_{2} \mathrm{O}\right.$ related $\left.\mathrm{SiO}_{2}\right)$ were used to identify the rock name, suggesting that one of Nang Rong Columnar Jointed Basalts (3AA) is basaltic trachyandesite. Three samples of Nang Rong Columnar Jointed Basalts (4AA, 5AA, 6AA) were basaltic andesite (Fig. 4a). Moreover, trace elements $(\mathrm{Zr} / \mathrm{Ti}$ related $\mathrm{Nb} / \mathrm{Y}$ ) determined that all samples were alkaline basalt (Fig. 4b).

Additionally, the origin magma series by total alkaline analysis plotted of $\mathrm{K}_{2} \mathrm{O}$ against $\mathrm{Na}_{2} \mathrm{O}$ (follow the theory of Mullen 1983) determined that Nang Rong Columnar Jointed Basalts were the sodic magma series (Na-Series). Three ternary discrimination diagrams were used to interpret the tectonic eruption of the studied basalts (Fig. 5). The trace elements diagrams both Ti-Zr-Y and Nb-Zr-Mn (Pearce, Cann 1973) determined all samples were within-plate alkaline

Table 1. Geochemical data presents major oxides and trace elements.

\begin{tabular}{|c|c|c|c|c|c|}
\hline \multicolumn{2}{|c|}{ Rock Sample } & $1 \mathrm{AA}$ & $2 \mathrm{AA}$ & 3AA & $4 \mathrm{AA}$ \\
\hline \multicolumn{2}{|c|}{ Location in local coordinations } & 2636321613808 & 2637071613202 & 2636381613808 & 2636621613218 \\
\hline \multirow[t]{11}{*}{ Major oxides [wt \%] } & $\mathrm{Al}_{2} \mathrm{O}_{3}$ & 15.98 & 16.28 & 15.82 & 16.03 \\
\hline & $\mathrm{Fe}_{2} \mathrm{O}_{3}$ & 8.89 & 8.92 & 9.44 & 8.85 \\
\hline & $\mathrm{K}_{2} \mathrm{O}$ & 1.39 & 1.25 & 1.31 & 1.24 \\
\hline & $\mathrm{MgO}$ & 5.04 & 4.91 & 5.49 & 4.87 \\
\hline & $\mathrm{MnO}$ & 0.18 & 0.09 & 0.07 & 0.07 \\
\hline & $\mathrm{Na}_{2} \mathrm{O}$ & 1.87 & 1.77 & 1.81 & 1.81 \\
\hline & $\mathrm{P}_{2} \mathrm{O}_{5}$ & 0.78 & 0.80 & 0.74 & 0.75 \\
\hline & $\mathrm{SiO}_{2}$ & 54.41 & 54.74 & 55.26 & 55.81 \\
\hline & $\mathrm{TiO}_{2}$ & 2.57 & 2.59 & 2.45 & 2.50 \\
\hline & $\mathrm{CaO}$ & 7.35 & 7.05 & 6.78 & 6.87 \\
\hline & LOI & 1.54 & 1.60 & 0.82 & 1.19 \\
\hline \multirow[t]{18}{*}{ Trace elements [ppm] } & $\mathrm{V}$ & 0 & 154 & 223 & 151 \\
\hline & $\mathrm{Cr}$ & 145 & 99 & 114 & 97 \\
\hline & Co & 188 & 193 & 206 & 208 \\
\hline & $\mathrm{Ni}$ & 67 & 88 & 69 & 81 \\
\hline & $\mathrm{Cu}$ & 31 & 25 & 26 & 35 \\
\hline & $\mathrm{Zn}$ & 145 & 171 & 131 & 151 \\
\hline & $\mathrm{Rb}$ & 25 & 10 & 27 & 25 \\
\hline & $\mathrm{Sr}$ & 803 & 781 & 811 & 792 \\
\hline & Y & 20 & 18 & 21 & 20 \\
\hline & $\mathrm{Zr}$ & 223 & 202 & 217 & 215 \\
\hline & $\mathrm{Nb}$ & 26 & 21 & 25 & 23 \\
\hline & Sn & 30 & 38 & 33 & 43 \\
\hline & $\mathrm{Sb}$ & 36 & 0 & 0 & 0 \\
\hline & $\mathrm{Ba}$ & 340 & 366 & 398 & 360 \\
\hline & $\mathrm{La}$ & 0 & 0 & 117 & 0 \\
\hline & $\mathrm{Ce}$ & 0 & 175 & 0 & 122 \\
\hline & $\operatorname{Pr}$ & 0 & 0 & 199 & 0 \\
\hline & $\mathrm{Nd}$ & 426 & 0 & 278 & 435 \\
\hline
\end{tabular}




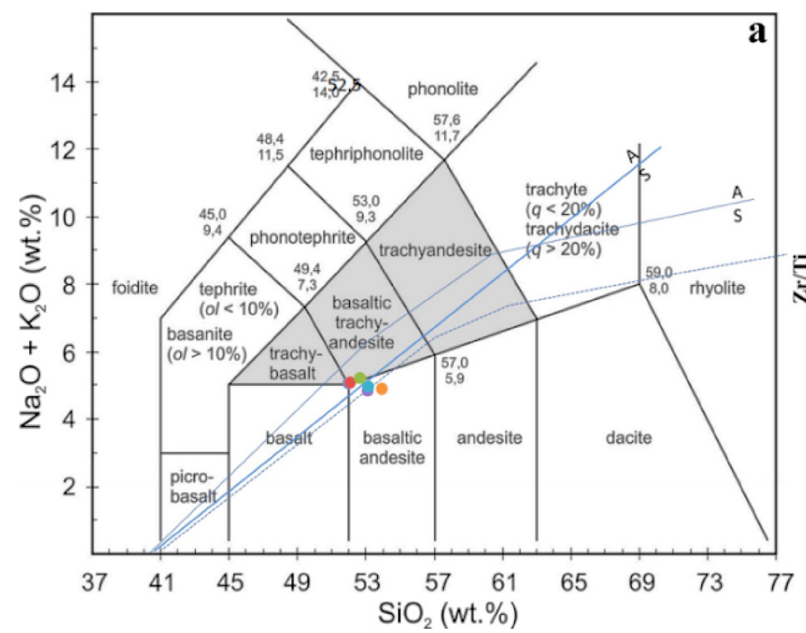

Fig. 4. Geochemistry data: a - TAS (total alkalines versus silica) diagram $\left(\mathrm{SiO}_{2}\right.$ versus. $\left.\mathrm{Na}_{2} \mathrm{O}+\mathrm{K}_{2} \mathrm{O}\right)$ and alkaline discrimination diagrams (diagram modified from Billings 1954, Le Bas et al. 1986); b - plot of Zr/ $\mathrm{Ti}$ against $\mathrm{Nb} / \mathrm{Y}$ (diagram modified from Yoder, Tilley 1962, Winchester, Floyd 1977) for the studied basalts.
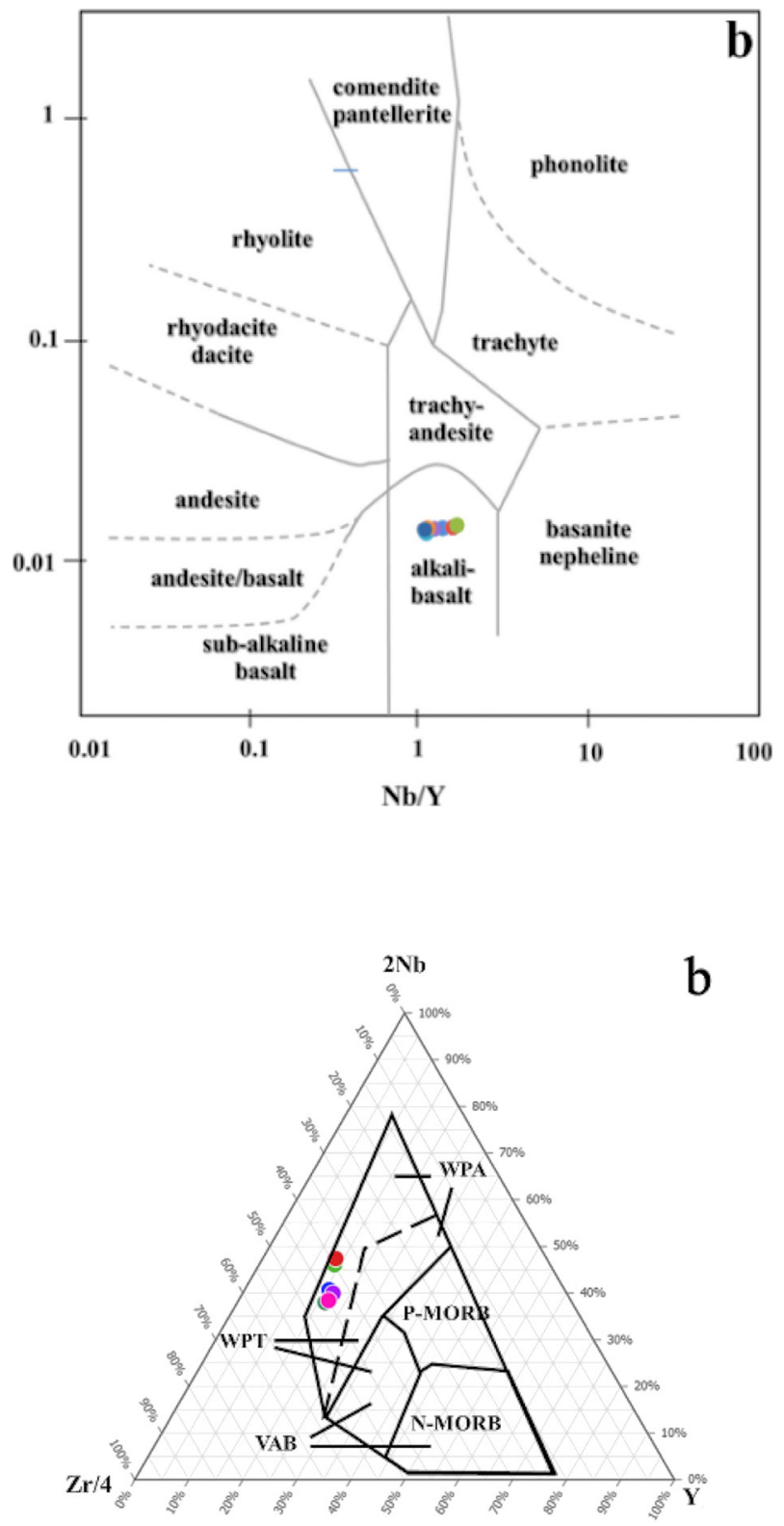

b

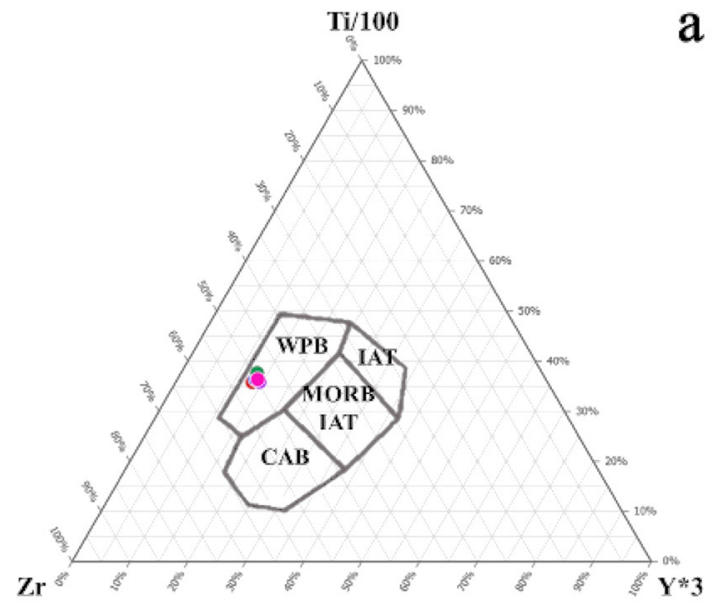

a

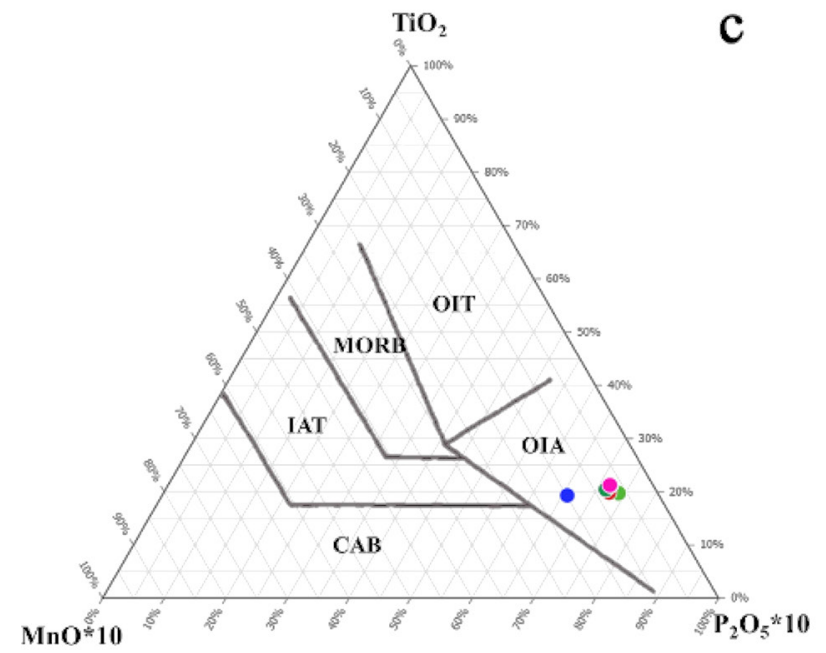

Fig. 5. The discrimination diagrams for the studied rocks; a - Ti-Zr-Y diagram, $\mathrm{b}-\mathrm{Nb}-\mathrm{Zr}-\mathrm{Y}$ diagram, and c $\mathrm{TiO}_{2}-\mathrm{MnO}-\mathrm{P}_{2} \mathrm{O}_{5}$ diagram (diagram modified from Sun, McDonough 1989, Pearce, Cann 1973). 
basalt (WPB, WPA), while the major oxides $\left(\mathrm{TiO} 2-\mathrm{MnO}-\mathrm{P}_{2} \mathrm{O}_{5}\right.$ ) in the oceanic tectonics diagram (Sun, McDonough 1989) classified all samples as oceanic island alkaline (OIA). Therefore, plotted OIA field support the continental plate of the Khorat Plateau that had been thinning during the basalt eruption (Cenozoic era) from the mantle plume beneath the surface as a hotspot (less evolved magma like the oceanic crust).

\section{Geological engineering}

Table 2 demonstrates the diameter and geological engineering of both columnar basalts (20 samples) and platy basalts (20 samples) in the site. The impact strength $\left(\mathrm{Is}_{50}\right)$ test is performed as CS and a point load strength index in Figure 6. The CS of columnar basalt (cj) is $54.57 \mathrm{MPa}$, while platy basalt (pj) is $50.23 \mathrm{MPa}$ (CS (cj) >CS (pj)), which is $7.94 \%$ less than columnar basalt. The point load strength index of columnar basalt is $4.01 \mathrm{MPa}>23.81 \%$ of platy basalt that is $3.06 \mathrm{MPa}\left(\mathrm{Is}_{50}(\mathrm{cj})>\mathrm{Is}_{50}(\mathrm{pj})\right)$. According to geological engineering analyses, columnar basalts have more strength than platy basalts based on numerous data. Many researchers, i.e. Ji et al. (2017), Fepuleai and Nemeth (2019), Vasseur and Wadsworth (2019), Xia et al. (2019), Smith and Holden (2020) studied geoengineering of columnar basalts and blended them into global aspects, especially in a geoheritage framework. Local slope failure mechanisms such as toppling and planar sliding are controlled by variations

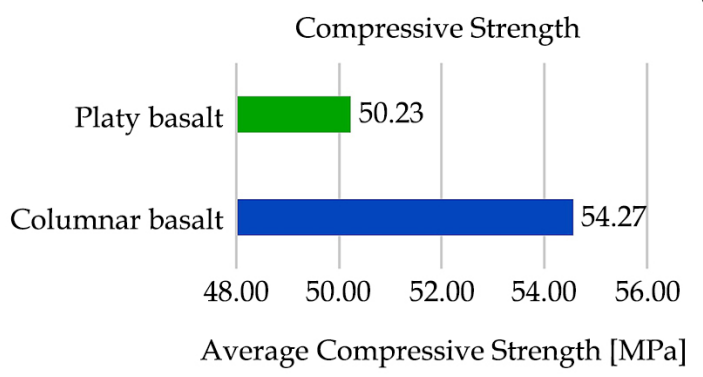

$\mathrm{b}$

Point load index

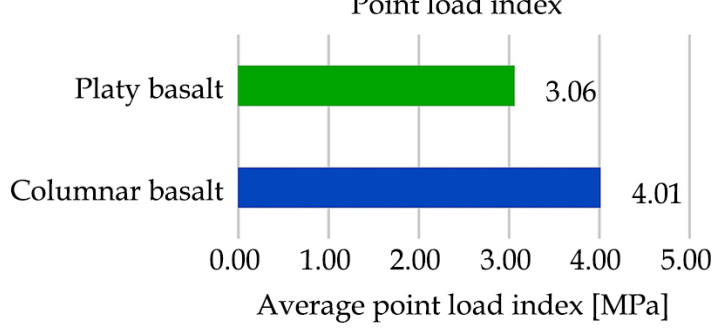

Fig. 6. Geological engineering data a - the average CS and $b$ - the point load index of studied basalts. CS, compressive strength.

Table 2. Geoengineering data presents diameter $(D)$, load $(P)$, point load index $(I s)$, geometric correction factor $(F)$, and impact strength $\left(I s_{50}\right)$.

\begin{tabular}{|r|c|c|c|c|c|c|c|c|c|c|}
\hline \multirow{2}{*}{ No. } & \multicolumn{9}{|c|}{ Columnar basalt } & \multicolumn{5}{c|}{ Platy basalt } \\
\cline { 2 - 12 } & $D[\mathrm{~m}]$ & $P[\mathrm{kN}]$ & $I s[\mathrm{Mpa}]$ & $F[\mathrm{~m}]$ & $I s_{50}[\mathrm{MPa}]$ & $D[\mathrm{~m}]$ & $P[\mathrm{kN}]$ & $I s[\mathrm{Mpa}]$ & $F[\mathrm{~m}]$ & $I s_{50}[\mathrm{MPa}]$ \\
\hline 1 & 0.048 & 30.0 & 13.02 & 0.348 & 4.54 & 0.052 & 32.0 & 11.83 & 0.361 & 4.27 \\
\hline 2 & 0.046 & 22.0 & 10.40 & 0.342 & 3.55 & 0.057 & 22.0 & 6.77 & 0.376 & 2.55 \\
\hline 3 & 0.044 & 19.0 & 9.81 & 0.335 & 3.29 & 0.045 & 11.0 & 5.43 & 0.338 & 1.84 \\
\hline 4 & 0.059 & 23.0 & 6.61 & 0.382 & 2.53 & 0.062 & 25.0 & 6.50 & 0.391 & 2.54 \\
\hline 5 & 0.043 & 30.0 & 16.22 & 0.332 & 5.38 & 0.064 & 22.0 & 5.37 & 0.397 & 2.13 \\
\hline 6 & 0.046 & 37.0 & 17.49 & 0.342 & 5.98 & 0.047 & 22.0 & 9.96 & 0.345 & 3.44 \\
\hline 7 & 0.054 & 40.0 & 13.72 & 0.367 & 5.04 & 0.054 & 20.0 & 6.86 & 0.367 & 2.52 \\
\hline 8 & 0.055 & 46.0 & 15.21 & 0.370 & 5.63 & 0.051 & 23.0 & 8.84 & 0.358 & 3.17 \\
\hline 9 & 0.044 & 44.0 & 22.73 & 0.335 & 7.61 & 0.043 & 20.0 & 10.82 & 0.332 & 3.59 \\
\hline 10 & 0.052 & 29.0 & 10.72 & 0.361 & 3.87 & 0.050 & 18.0 & 7.20 & 0.355 & 2.55 \\
\hline 11 & 0.045 & 26.0 & 12.84 & 0.338 & 4.34 & 0.050 & 19.0 & 7.60 & 0.355 & 2.70 \\
\hline 12 & 0.055 & 31.0 & 10.25 & 0.370 & 3.80 & 0.050 & 18.0 & 7.20 & 0.355 & 2.55 \\
\hline 13 & 0.051 & 32.5 & 12.50 & 0.358 & 4.47 & 0.060 & 35.0 & 9.72 & 0.385 & 3.74 \\
\hline 14 & 0.058 & 28.0 & 8.32 & 0.379 & 3.16 & 0.048 & 8.0 & 3.47 & 0.348 & 1.21 \\
\hline 15 & 0.054 & 12.0 & 4.12 & 0.367 & 1.51 & 0.045 & 20.0 & 9.88 & 0.338 & 3.34 \\
\hline 16 & 0.051 & 32.0 & 12.30 & 0.358 & 4.40 & 0.039 & 29.0 & 19.07 & 0.317 & 6.05 \\
\hline 17 & 0.043 & 16.0 & 8.65 & 0.332 & 2.87 & 0.049 & 18.0 & 7.50 & 0.352 & 2.64 \\
\hline 18 & 0.048 & 21.0 & 9.11 & 0.348 & 3.18 & 0.043 & 15.0 & 8.11 & 0.332 & 2.69 \\
\hline 19 & 0.053 & 20.0 & 7.12 & 0.364 & 2.59 & 0.052 & 24.0 & 8.88 & 0.361 & 3.21 \\
\hline 20 & 0.047 & 16.0 & 7.24 & 0.345 & 2.50 & 0.040 & 22.0 & 13.75 & 0.321 & 4.41 \\
\hline
\end{tabular}


in the pattern of columnar joint orientations. Landslides and rockfalls of volcanic rocks are common landscape sculpting processes in tropical climates (Fepuleai, Nemeth 2019). Their common creation poses a risk to populations and tourists; hence, studying their formation and recognition on modern landscapes is an important part of teaching local residents and developing mitigation methods for future disasters. However, the evidence in this case study shows that the frequently held belief that columnar joints have a simple parallel pattern cannot be assumed (Smith, Holden 2020).

\section{Assessment and SWOT analysis}

The columnar basalt in Nang Rong displays many values, especially geology, tourism, economy, education and culture (Fig. 7). The area is the greatest columnar basalt and significant volcanic landforms, which erupted during the Cenozoic period on the Khorat plateau (Fig. 1). According to the strength, the basalt terrain in Buriram was exploded for rock quarry for construction in the past. Thus, this area is the post-mining area that should be developed for a good environment and better livelihood of local people nowadays, similar to basalt quarrying sites in England, France, New Zealand, Poland and Spain as well as Su
Nuraxi di Barumini, the World Heritage Site in Italy (Maria Mateos et al. 2011, Migoń, PijetMigoń 2016, Prosser 2018, Careddu, Grillo 2019, Comentale 2019, Nemeth et al. 2021). Many undergraduate students from various universities (Khon Kaen, Chiang Mai, Buriram Rajabhat universities) come to research this post-mining area in both geology and tourism to increase educational value (Fig. 8a). The Nang Rong Columnar Jointed Basalts presents many points about tourism values, especially management and promotion. This area contains an aesthetic viewpoint that magnetizes tourists to visit and join photograph and rafting (a pastime of travelling down a pond on a raft, which is made from bamboos and tyres) activities from August to January (Fig. 8b). Local authorities, government organisations, and universities have many connections and cooperation in planning the developed strategies (Fug. 8c). Local people create their shops to sell local foods, drinks and products related to the volcano and volcanic rocks (Fig. 8d). During the years 2020-2021, the tourists mass can rapidly develop an economic scheme and increase the advantage to nearby attractions. Visitors can learn the local people's lifestyle and their unique language that present a very symphonic 'Isan' language (words and accent (smooth) difference from other Thai languages). There are many historical sites and volcanic landforms not far from this area

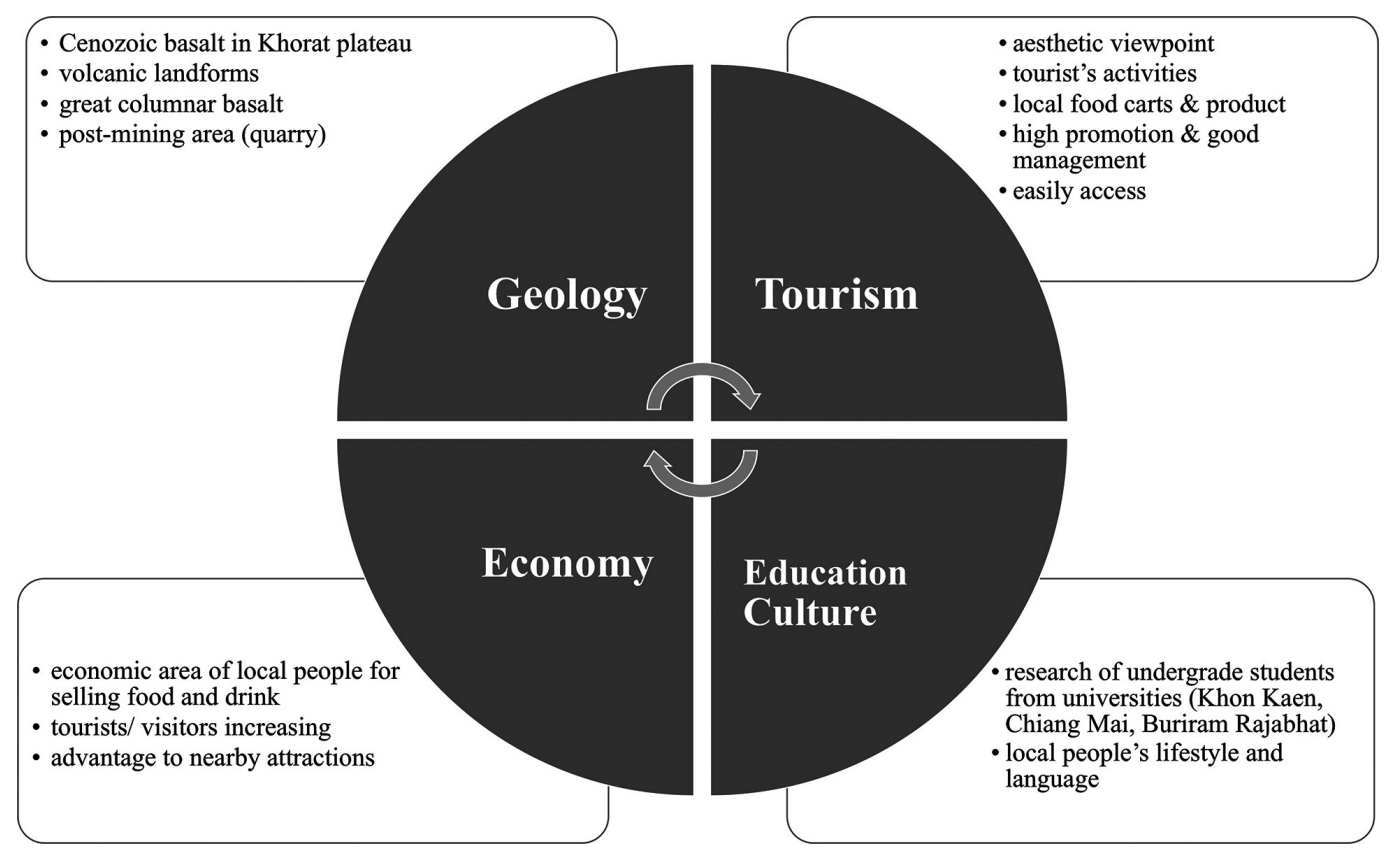

Fig. 7. The model of alkaline columnar basalt in Buriram Terrain, Thailand. 

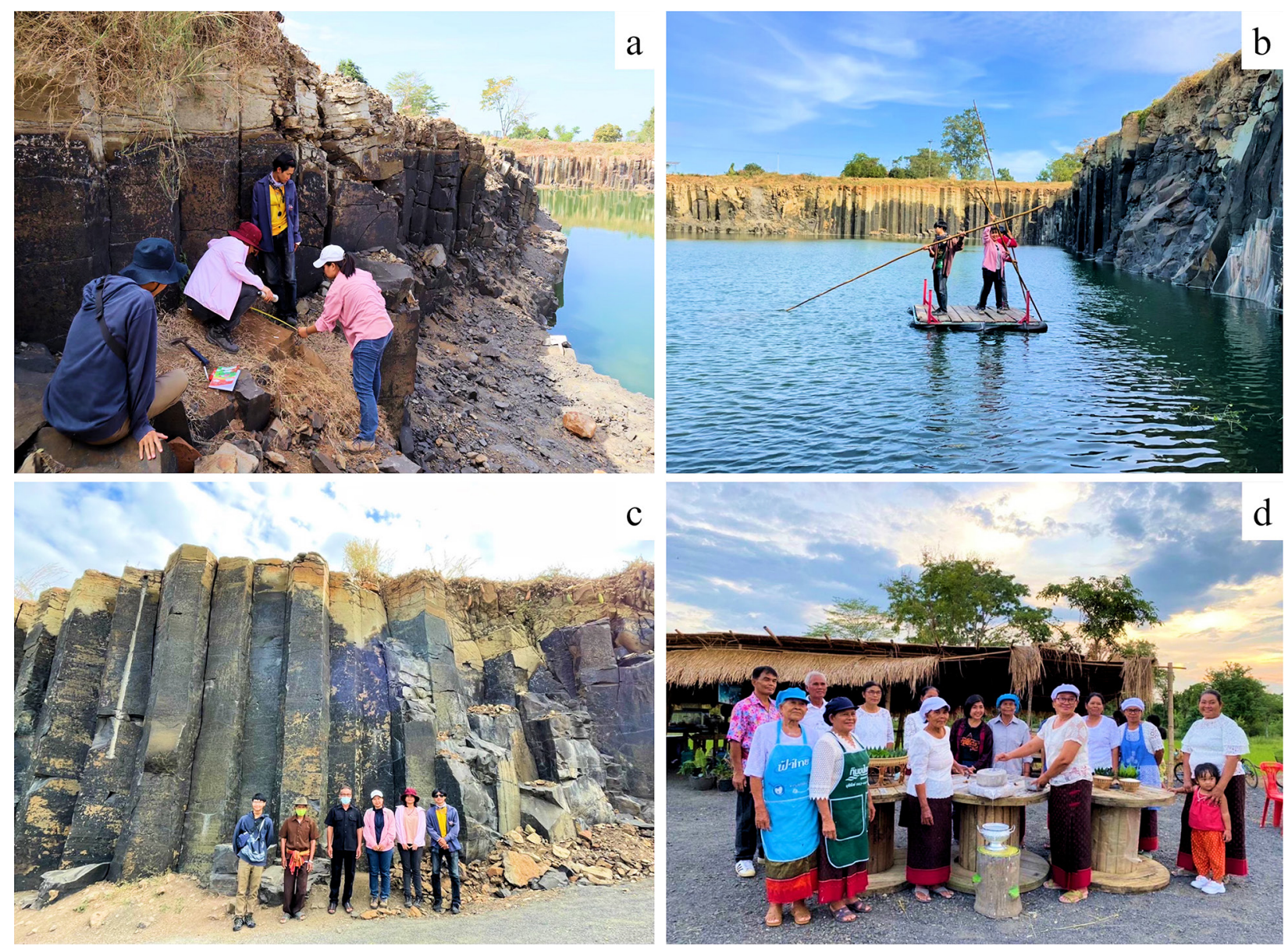

Fig. 8. Geotourism Perspectives: a - research activity of Geotechnology undergraduate students, $\mathrm{b}$ - rafting activities, c - local authorities, local people, and students group shot d - local people and their food carts.

\section{S: Strengths}

- greatest columnar basalts

- easily access

- many local food carts

- activities i.e. rafting, imaging

- high promotion

- local products related to volcano

\section{W: Weaknesses}

- no scientific panel

\section{O: Opportunities}

- prototype of post-mining management

- research in pure geology and geotourism

- geoeducation activities for local people and school

\section{SWOT}

\section{T: Threats}

- flooding in rainy season

- COVID-19 pandemic

Fig. 9. Basic assessment model in geology, tourism, economy, education and culture. 
$(<10 \mathrm{~km})$. In addition, local people try to produce their own products 'geofood' such as rice planted in volcanic soil, lava durian, and Pha Phu Akanee fabric dyeing volcanic soil.

According to the assessment, the Nang Rong Columnar Jointed Basalts shows some strengths and opportunities in SWOT analysis (Fig. 9). There are shortcomings such as lack of geoscientific data and no explanatory boards as well as the presence of the panel of scientists who can provide quality information for visitors to understand geology and earth's process in the area. However, this area is suitable for post-mining prototypes and could increase research in pure geology (i.e. petrology, mineralogy, geochemistry and geomorphology) and applied geology (i.e. engineering geology, hydrogeology, geotourism, mining geology and environmental management) through their identity, rarity and representativeness. The geoeducation activities can be developed and created for educating local people and schools to realise and conserve their geological monuments. During the years 2020-2021, the COVID-19 (Coronavirus disease) pandemic affected the tourism industry in this region, that resulted in economic losses. In addition, threat from natural disasters such as flooding in the rainy season, prevented visitors not to see any columnar basalt.

\section{Discussion for columnar model and geotourism development}

Basalt in Nang Rong Columnar Jointed Basalts presents porphyritic texture with olivine microphenocrysts. Platy basalt has the number of olivine microphenocrysts, slightly altered to iddingsite more significant than columnar basalt. In addition, plagioclase groundmass also exhibits trachytic texture, which indicates the Buriram basalt erupted as lava flow on the earth's surface. Geochemistry classified the studied rocks as basaltic trachyandesite and basaltic andesite by major oxides, while trace elements determined those as alkaline basalt. The origin of the magma series of Buriram volcanic terrain is alkaline. Nang Rong Columnar Jointed Basalts is alkaline-sodic magma series, while basalt in the Nang Rong Silathong active quarry is alkaline-potassic magma series. These basalts were erupted within the continental plates and exhibit oceanic island basalt-like characteristics. Moreover, the difference in shape crack $(\mathrm{Y}, \mathrm{X}$ and $\mathrm{T})$ of columnar basalts is caused by stress on the edge of the columnar face (Fig. 10), resulting in the new fissure section, and this part of the fissure is aligned along with the network of the resulting fissure (Billings 1954).

This area presents three essential stages for geoheritage development, as shown in Figure 11. The first stage is the basalt quarry that produced rock aggregates for construction in the past. This stage describes georesources management in Buriram province, where people primarily use basalt for construction, which is different from other regions in Thailand where they use limestone (data from Nationwide mining license information of Department of Primary Industries and Mines 2009). After mining activities, the area becomes the columnar basalt geoheritage and impress visitors in geological phenomena.

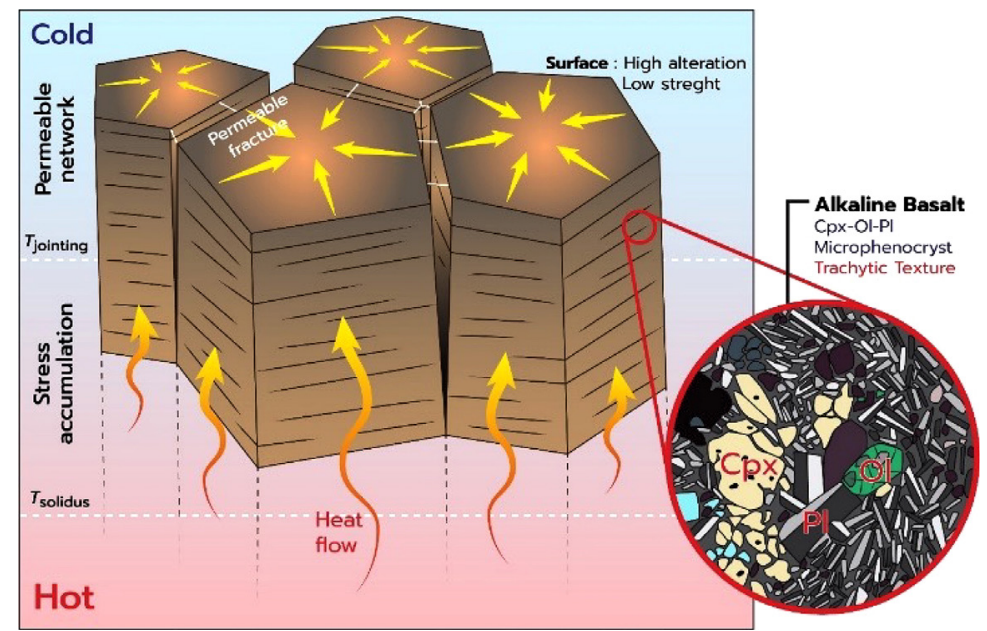

Fig. 10. SWOT analysis for geotourism strategic planning. SWOT: strengths-weaknesses-opportunities-threats. 


\section{Basalt Quarry}

Produced rock aggregates for construction

Columnar Basalt Geoheritage

Destination for tourists managed by local people

Prototype of Post-Mining Geoheritage

Geotourism and Geo-Education development

Fig. 11. Timeline development of Nang Rong Columnar Jointed Volcanics from active quarry to post-mining geoheritage.

Many tourists call this area as 'Grand Canyon Buriram' in Thai and denominate this area similar to Iceland (data from Google Trend 20202021). So, this area is a famous destination for tourists managed by local people and is promoted by many tourists via Facebook pages, personal blocks and webpages. The Ban Khok Makha Ron, Sadao Sub-district, Nang Rong District, Buriram province is supported by local authorities, researchers, and government organisations for developing local people and communities toward sustainability via Community-Based Tourism (CBT). Thus, the studied area is presently suitable to be the prototype of post-mining geoheritage. Geotourism and geo-education development will be developed through tourist activities i.e. Thai geologist's travel trip shared their knowledge in social media, and many people quickly access geological knowledge of Nang Rong Columnar Jointed Basalts. This work can be an excellent example for developing the post-mining area in geoeducation model by cooperation between local people, local authorities and researchers from universities via research, field trips and related activities, even in recreation and business schemes.

\section{Conclusion}

Nang Rong Columnar basalt presents a porphyritic texture with olivine microphenocrysts. Platy basalt has the number of olivine microphenocrysts, slightly altered to iddingsite more significant than columnar basalt. Major oxides classified the studied rocks as basaltic trachyandesite and basaltic andesite, while trace elements determined those as alkaline basalt. The Nang Rong Columnar Jointed Basalts generated from the alkaline-sodic magma series and erupted within the continental plates. Iddingsite 15.70 modal\% in platy basalt and 10.06 modal\% in columnar basalt $(>5.63 \%)$, possibly due to the rapid change in the surface temperature of lava, showing a crack and joint. While the temperature inside lava flow is relatively constant, making it a characteristic of the sizeable columnar joint. Thus, the microphenocryst, the primary set of crystallisation and altered to iddingsite, appears abundantly in platy basalt 35.89 modal\%. In addition, The petrochemistry of studied basalts supported that significant differences in characteristics were found to affect the strength of both columnar and platy joint types. According to high geological, tourism, and economic values, this Nang Rong columnar basalt is the high potential area for creating a prototype of post-mining geoheritage in Thailand. Geotourism and geoeducation can be developed through the recent trend of touristic activities among visitors, managed by local people.

\section{Acknowledgements}

The authors would like to express gratitude to the Department of Geotechnology, Faculty of Technology, Khon Kaen University for all types of equipment and laboratories as well as opportunities. In addition, thanks are also to the reviewers and related persons for their valuable comments, advice and encouragement throughout the research to accomplish very well.

\section{Author's contribution}

S.V.: $75 \%$ - conducting research, research methodology and data analysis, software, making figures, study area description, preparation of the manuscript, preparation of the discussion chapter; preparation of the discussion chapter; A.A.: 25\% - conducting research, data analysis; preparation of the discussion chapter. All authors have read and agreed to the published version of the manuscript.

\section{References}

ASTM [ASTM International], 2014. Standard test method for determination of rock hardness by Rebound Hammer Method, (ASTM D 5873). 
Barr S.M., MacDonald A.S., 1981. Geochemistry and geochronology of late Cenozoic basalts of Southeast Asia: Summary. Geological Society of America Bulletin 92(1): 508-512.

Billings M.P., 1954. Structural geology. Prentice Hall, Englewood Cliffs, NJ.

Bohle M., Di Capua G., 2019. Setting the scene. In: Martin B. (ed.), Exploring geoethics. Palgrave Pivot, Cham: 1-24. DOI 10.1007/978-3-030-12010-8_1.

Bohle M., Di Capua G., Bilham N., 2019. Reframing geoethics? In: Martin B. (ed.), Exploring geoethics. Palgrave Pivot, Cham: 165-174. DOI 10.1007/978-3-030-12010-8_5.

Careddu N., Grillo S.M., 2019. Sardinian Basaltan ancient georesource still en vogue. Geoheritage 11(1): 35-45. DOI 10.1007/s12371-018-0285-0.

Comentale B., 2019. Disused stone quarries in urban landscape, a feature of geoheritage: case studies from Paris and Nantes. Physio-Geo 13: 1-24. DOI 10.4000/physio-geo.7198.

Department of Primary Industries and Mines, 2009. Nationwide mining license information. Bureau of Mines and Concession, Department of Primary Industries and Mines, Bangkok.

Di Capua G., Peppoloni S. 2019. Defining geoethics. Website of the IAPG - International Association for Promoting Geoethics. Online: www.geoethics.org/definition (accessed 15 December 2021).

DMR [Department of Mineral Resources], 2001. Mineral statistics of Thailand (1994-2000). Technic and Planning Division, Department of Mineral Resources, Bangkok.

DMR [Department of Mineral Resources], 2007. Geologic Map of Buriram Province. Online: www.dmr.go.th/download/ pdf/NorthEast/burirum.pdf (accessed 29 October 2020).

Fepuleai A., Nemeth K., 2019. Volcanic geoheritage of landslides and rockfalls on a tropical ocean Island (Western Samoa, SW Pacific). Geoheritage 11(2): 577-596. DOI 0.1007/s12371-018-0306-z.

Hamada A., Toramaru A., 2020. Analogue experiments on morphological transition from colonnade to entablature of columnar joints. Journal of Volcanology and Geothermal Research 402: 106979. DOI 10.1016/j.jvolgeores.2020.106979.

Hetenyi G., Taisne B., Garel F., Medard E., Bosshard S., Mattsson H.B., 2012. Scales of columnar jointing in igneous rocks: field measurements and controlling factors. Bulletin of Volcanology 74(2): 457-482. DOI 0.1007/ s00445011-0534-4.

ISRM [International Society for Rock Mechanics and Rock Engineering], 1985. Commission on testing methods. Suggested method for determining Point Load Strength, Ankara: ISRM Turkish National Group. 22: 51-60.

Ji H., Zhang J.C., Xu W.Y., Wang R.B., Wang H.L., Yan L., Lin Z.N., 2017. Experimental investigation of the anisotropic mechanical properties of a columnar jointed rock mass: Observations from laboratory-based physical modelling. Rock Mechanics and Rock Engineering 50(7): 1919-1931. DOI 10.1007/s00603-017-1192-4.

Le Bas M.J., Le Maitre R.W., Streckeisen A., Zanettin B., 1986. A chemical classification of volcanic rocks based on the total alkali-silica diagram. Journal of Petrology 27: $745-750$

Li Y.Q., Liu J.Z., 2020. Late Cenozoic columnar-jointed basaltic lavas in eastern and southeastern China: morphologies, structures, and formation mechanisms. Bulletin of Volcanology 82(7): 58. DOI 10.1007/s00445-020-01397-1.
Mallet R., 1875. On the origin and mechanism of production of the prismatic (or columnar) structure of basalt. American Journal of Science 3-9(51): 206-211.

Maria Mateos R., Duran J.J., Robledo P.A., 2011. Mares quarries on the Majorcan Coast (Spain) as geological heritage sites. Geoheritage 3(1): 41-54. DOI 10.1007/s12371-0100026-5.

Middlemost E.A.K., 1975. The basalt clan. Earth-Science Reviews 11: 337-364.

Migoń P., Pijet-Migoń E., 2016. Overlooked geomorphological component of volcanic geoheritage-diversity and perspectives for tourism industry, Pogrze Kaczawskie Region, SW Poland. Geoheritage 8(4): 333-350. DOI 10.1007/ s12371-015-0166-8.

Mullen E.D., 1983. $\mathrm{MnO} / \mathrm{TiO}_{2} / \mathrm{P}_{2} \mathrm{O}_{5}$ : a minor element discriminant for basaltic rocks of oceanic environments and its implications for petrogenesis. Earth and Planetary Science Letters 62: 53-62.

Nazaruddin D.A., 2019. Selected geosites for geoheritage, geotourism, and geoconservation in Songkhla Province, Southern Thailand. Quaestiones Geographicae 38(1): 161177. DOI 10.2478/quageo-2019-0011.

Nazaruddin D.A., 2020. Granite landforms of Samui Island (southern Thailand) from geoheritage, geoconservation and geotourism perspectives. International Journal of Geoheritage and Parks 8: 75-86. DOI 10.1016/j. ijgeop.2020.05.003.

Nemeth K., Gravis I., Nemeth B., 2021. Dilemma of geoconservation of monogenetic volcanic sites under fast urbanization and infrastructure developments with special relevance to the Auckland volcanic field, New Zealand. Sustainability 13(12): 6549. DOI 10.3390/su13126549.

Pearce J.A., Cann J.R., 1973. Tectonic setting of basic volcanic rocks determined using trace element analyses. Earth and Planetary Science Letters 19: 290-300.

Prosser C.D., 2018. Geoconservation, quarrying and mining: Opportunities and challenges illustrated through working in partnership with the mineral extraction industry in England. Geoheritage 10(2): 259-270. DOI 10.1007/s12371016-0206-Z.

Singtuen M., Won-In K., 2017. Geotourism and sustainable development perspectives of the Khao PhraWihan National Park on the southern edge of the Khorat Plateau, Thailand. In: Proceedings of the 8th International Conference on Environment, Agriculture, Biology and Natural Sciences (EABNS-2017). Bangkok: 39-45.

Singtuen V., Gałka E., Phajuy B., Won-in K., 2019. Evaluation and geopark perspective of the geoheritage resources in Chiang Mai Area, Northern Thailand. Geoheritage 11: 1955-1972. DOI 10.1007/s12371-019-00410-0.

Singtuen V., Phajuy B., 2020. Archaeological distribution of geoheritage for geotourism development in Nakhon Sawan Province, Thailand. Quaestiones Geographicae 39(3): 57-68. DOI 10.2478/quageo-2020-0023.

Singtuen V., Won-In K., 2018a. An assessment of the potential island for geotourism value in Ko Kham Undersea Park, Chonburi, Gulf of Thailand. In: Proceedings of the BRegional Geoheritage Conference 2018 with the theme BGeoheritages for People. Khonkaen: 11-18.

Singtuen V., Won-In K., 2018b. Geodiversity and geoconservation of the Chaiyaphum region in Thailand for sustainable geotourism planning. Geojournal of Tourism and Geosites 22: 548-560. DOI 10.30892/gtg.22223-310.

Smith J.V., Holden L., 2020. Rock slope kinematic instability controlled by large-scale variation of basalt column 
orientation. Bulletin of Engineering Geology and the Environment 80(4): 239-250. DOI 10.1007/s10064-020-01917-5.

Sun S.S., McDonough W.F., 1989. Chemical and isotopic systematics of oceanic basalts; implications for mantle composition and processes. Journal of the Geological Society 42: 313-345.

Tietz O., Buechner J., Lapp M., Scholle T., 2018. The Stolpen Volcano in the Lausitz Volcanic Field (East Germany) volcanological, petrographic and geochemical investigations at the type locality of basalt. Journal of Geosciences 63(4): 299-315. DOI 10.3190/jgeosci.275.

USGS, 2021. Mineral resources online spatial data, interactive maps and downloadable data for regional and global analysis. Online: mrdata.usgs.gov/ (accessed 15 December 2021).

Vasseur J., Wadsworth F.B., 2019. The permeability of columnar jointed lava. Journal of Geophysical Research-Solid Earth 124(11): 11305-11315. DOI 10.1029/2019jb018118.
Winchester J.A., Floyd P.A., 1977. Geochemical discrimination of different magma series and their differentiation products using immobile elements. Chemical Geology 20: 325-343.

Xia Y., Zhang C., Zhou H., Zhang C., Hong W. 2019. Mechanical anisotropy and failure characteristics of columnar jointed rock masses (CJRM) in Baihetan hydropower station: Structural considerations based on digital image processing technology. Energies 12(19): 3602. DOI 10.3390/en12193602.

Yan Q., Shi X., Metcalfe I., Liu S., Xu T., Kornkanitnan N., Sirichaiseth Th., Yuan L., Zhang Y., Zhang H., 2018. Hainan mantle plume produced late Cenozoic basaltic rocks in Thailand, Southeast Asia. Nature 8(1): 1-14. DOI 10.1038/ s41598-018-20712-7.

Yoder H.S., Tilley C.E., 1962. Origin of basalt magmas; an experimental study of natural and synthetic rock systems. Journal of Petrology 3(3): 342-529. 